\title{
MIGRANTS' REMITTANCES AND PUBLIC EXPENDITURE ON EDUCATION NEXUS: EVIDENCE FROM AN OIL-DEPENDENT ECONOMY
}

\author{
Sunday Osahon Igbinedion*, Clement Atewe Ighodaro \\ Department of Economics, Faculty of Social Sciences, University of Benin, Edo State, \\ Nigeria \\ sunday.igbinedion@uniben.edu \\ clement.ighodaro@uniben.edu
}

\begin{abstract}
This study examined migrants' remittances, public expenditure on education and their implications for educational development in Nigeria, using Secondary School enrolment rates (SSER) as a proxy for the latter for the period 1981 to 2017. The study utilised Cointegration and error correction modelling approach in order to minimise the likelihood of producing explosive regression estimates. The empirical findings of the study indicate that Migrants' remittances received, Public expenditures on Education and Per Capita Income growth rate exert statistically significant positive impacts on educational development in the country, while the association turned negative in the case of population growth rate. The fundamental role played by both migrant's remittances received and Public expenditures on Education in stimulating educational development was evidently established in the study. The study therefore recommends, among others, the adoption of strategic measures that will help boost the rate of school enrolment in the country by encouraging migrants' remittances through continuous engagement of Nigerians in the Diaspora in the country's political and socio-economic affairs, progressive increment in budgetary allocations to the nation's education sector, as well as enhancing the per capita income of the country through investments in key sectors of the nation's economy.
\end{abstract}

Keywords: Migration, Remittance, Public Expenditure on Education, Educational Development, Nigeria.

JEL classification: F22, F24, H52, I22

\section{Introduction}

Over the last few years, a substantial volume of studies have been carried out on how human capital development has been influenced by the joint forces of Migration, Remittances and Public Expenditure on Education across several countries of the world. It is worthy to note that, most of the early research on immigration programme hypothesised that immigrants move from their respective countries, move into another country, adapt to the settings of the new social order, and gradually wane their bonds with their ancestral home of origin. In the present days, the wave of globalization permits immigrants to retain the bonds with their country of origin while living in a foreign country, thus abating the likelihood of forfeiting their original identity and parting from their native countries.

Remittances, simply described as the cash transactions carried out by migrants in favour of their beneficiaries such as relations and friends back home, have progressively attracted the attention of researchers and policymakers as they continue to increase in volume and their significant impact on the development of the nation's economy becomes more explicit and profound. For instance, it is projected that approximately 15 million Nigerians settle and work in foreign countries and draw substantial volumes of remittances to their home countries

\footnotetext{
${ }^{*}$ Corresponding author: Sunday Osahon Igbinedion
} 
(Nigeria) on an annual basis. In 2016, statistical report from the World development indicators of the World Bank on official remittances reveal that, Nigerians living abroad remitted approximately 20 billion dollars (World Bank, 2016) with the likelihood that the amount will soar high in successive years sequel to the government recent efforts in engaging Nigerians living abroad in various national development programmes.

Over the years, it has been acknowledged that a preponderant number of Nigerians living in foreign countries account for a powerful driving force for national progress. Such indication largely revolves around investments and remittances in the area of monetary contributions. However, in recent times, there has been an increasing awareness of the likely impact of Nigerians in diaspora on national development in terms of non-financial commitments. Thus, much as remittances may have the tendency to significantly affect the nation's economy, it is necessary to map out channels through which Nigerian diaspora are encouraged to contribute to national development. The practice of enhancing the smooth flow of skills and information from overseas to Nigeria with a view to boosting the development of the education sector informs the need to acknowledge the significance and effectiveness of diaspora's expertise and proficiencies in that sector.

In 2016, statistical report from the World development indicators of the World Bank on migration indicates that the number of persons who reside outside their native countries globally rose from 153 million in 1990 to about 249 million in 2016, and this represents approximately 2.87 percent of the global population in the year 1990 and about 3.32percnet of the world population in the year 2016. Similar report reveals that, the total sum of remittance receipts grew from approximately $\$ 68$ billion in 1990 to about $\$ 558$ billion in 2016. On the average, the volume of remittances received from Diaspora (in 2011 constant dollars) rose from about $\$ 688$ in 1990 to roughly $\$ 2128$ in 2016. These figures, however, only reflect the amount of remittances that have been received through official platforms.

In the nation's determined efforts to substantially augment the knowledge, expertise and involvement of Nigerian professionals overseas in various national development agenda, the Nigerian government swigged into action in 1999 by enacting foreign policies to boost Diaspora's involvement in National affairs. These policies further came to limelight through the nomination of three Nigerian academic professionals in the diaspora as Vice Chancellors of three (3) newly-created institutions of higher learning (Universities) in 2011. The idea was to rejuvenate the nation's system of higher education in the course of meritoriously attracting Nigerians in the diaspora to render their inputs in various sectors of the nation's economy. The implication of the above measures can be evaluated from the ease at which the newly appointed academic scholars were able to draw several other prominent Nigerian professors abroad to come back to their native country to contribute their quota as pioneer professors in the newly established universities.

Government expenses on education on the other hand, are imperative disbursement items universally. The extent to which the sector receives the attention of players in both public and private sectors has an unswerving and significant bearing on economic development through human capital development. In Nigeria, budgetary allocations to formal education are positively skewed in favour of secondary and tertiary institutions which larger share of public financing than primary education in the country. Relatively, however, most institutions in Nigeria are starved of financing while several relevant infrastructures are lacking, a development that has been partly blamed for the resultant poor outputs from these institutions.

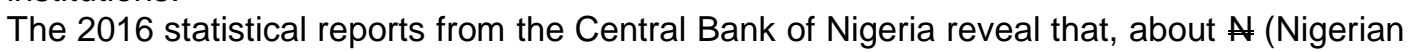
Currency) 57.95 billion was allocated to the Nigerian education sector in the year 2000 . The figure increased to about $\$ 335.8$ billion and $\$ 341.88$ billion in 2011 and 2016 respectively. Despite the increasing financial inflows from Remittances and a sizeable amount of public spending on the Education sector, most Nigerian schools still suffer from over-enrolment of students, poor sanitation, maladministration and abandoned capital projects. This 
repeatedly translates into shut down of schools and frequent strike actions by various academic and non-academic bodies with the resultant and combined effects of reduced quality of education and training which in turn lead to low quality of outcomes.

Though a handful of studies have been carried out on the relative impact of migrants' remittances and government expenditure on educational development, most of such studies have either been panel studies, or have been conducted outside the confines of the Nigerian economy as in the case of Ratha (2007) for Ghana and Lu and Treiman (2007) for South Africa. Replicating the policy prescription(s) from such panel studies or country-specific studies for the Nigerian economy may be quite misleading. Besides, the latest period examined by the authors was 2007 . And, considering the fact that the Nigerian economy has gone through series of educational reforms in the last one decade, makes the relevance of such policy recommendations doubtful.

This study therefore attempts to fill these gaps by investigating the relative impact of migrants' remittances and government expenditures on educational development within the context of Nigeria. Accordingly, the rest of the study is organized as follows; section two captures the review of relevant literature, while section three presents the model specification and methodology of the study. Lastly, the analysis of the results of the empirical survey is encapsulated in section four, while section five concludes the study.

\section{Review of Related Literature}

Several studies that have been carried out by scholars on the impact of migrant remittances and government expenditures on Education sector development have produced differing empirical outcomes. A number of scholars, predominantly from industrialised nations, are of the opinion that the influx of migrants remittances can significantly influence remittance-recipient nations in diverse channels, such as financial sector development, expansion of political institutions, inequality and poverty reduction, impact on growth and welfare, health and education outcomes (Cox Edwards and Ureta, 2003; Rapoport and Docquier, 2005; Gapen et al., 2009; Giuliano and Ruiz-Arranz, 2009; Rao and Hassan, 2011; Ziesemer, 2012; Ziesemer, 2012; Li and Zhou, 2013; Li and Zhou, 2015; Al Mamun et al., 2015; Bang, MitraandWunnava, 2016; Williams, 2017).

In every economy, migration plays a significant role in the development of human capital. Interestingly, in recent time, there is an emergent pool of empirical substantiation signifying that, a sizeable proportion of migrant remittances are channelled into the education sector (Adams, 2005; Adams et al. 2008 and Valero-Gil 2008). Migrants' children are associated with a higher likelihood of gaining access to quality education as they have the predisposition to complete their schooling on time. This is however attributed to the fact that, the rising earnings from remittances offer auxiliary financial supports and better projections connected to migration impact and inducements geared towards the attainment of more education (Cox-Edwards and Ureta 2003; Yang 2008; UNDP, 2009). Further empirical evidence from Pakistan reveals that short-term migration is directly related to rising school enrolment (Mansuri 2006).

Further analysis on the impact of Migrant Remittances on the development of the Education sector reveal that, a major disparagement raised against remittance inflows is that it does not sustain the recipients as they spend these inflows on direct consumption in an extravagant way (Cattaneo, 2010). Nonetheless, this finding contradicts the idea that most households invest remittances on human capital development. Several studies show that, an average remittance-receiving family invest more on education and health care when compared to those households that are not associated with this form of earnings and this facilitates higher educational accomplishment for families in the country of origin (Edwards and Manuelita, 2003; Richard, 2005; World Bank Development Prospects Group, 2006; Prabal and Dilip, 2012). 
Study by Benedictis, Calfat and Jara (2010) on the relationship between migrant remittances and child education in Ecuador with specific attention on the impacts on the conditions for education supply at the regional level substantiate previous findings that remittances exert positive impacts on child education. Similarly, a cross sectional analysis on 11 Latin American countries by Acosta (2011) reveals positive effect of migrant remittances on education. Similar survey of several households in Colombia by Medina and Cardona (2010) shows a significant impact of migrant remittances on education, whereby the recipient families spend approximately 10 per cent of their total international remittances on education compared to non-remittance receiving families.

The empirical findings on public expenditures on education and its implications for educational development have been inconsistent. For instance, Okeke (2014) examined the effects of government spending on aggregate school enrolment and under -5 mortality rate in Nigeria by utilising vector error correction mechanism (VECM). The empirical result shows that public spending on education has no statistically significant impact on total school enrolment in the country. Ime (2016) also examined public sector expenditure on education and human capital development in Nigeria and found that the expenditure on education in Nigeria has been far from satisfactory and lack the propensity to address the essentials of educational institutions whose enrolment is on a rapid increase.

On the other hand, Oriakhi and Ameh (2014) examined the effect of education expenditure on the level of literacy in Nigeria and found a statistically significant long-run association between public expenditures on education and literacy rate. Charles, et al. (2016) further examined government education spending and education outcome in Nigeria from 1970-2013 using Ordinary Least Square (OLS) technique. The empirical findings indicated that, Government expenditure on education is a statistically significant factor to be reckoned with, when discussing issues relating to the determinants of education outcomes in the country.

McMahon (1999) revealed a significant linkage between per pupil expenditures and the primary gross enrolment rate. He further submitted that, growing public education spending has a positive and significant bearing on gross enrolment rate. This corroborates the findings of Mingat and Tan (1992), Gupta, Verhoeven and Tiongsan (2002), Okonkwo (2014), Ude and Ekesiobi (2014), Adowaa (2014) and Jackson, Rucker and Persico (2015). Similar study by Ebejer and Ulrike (2009) evaluated the efficiency of public spending in Malta and found that, Government spending on education in Malta seems to be reasonably efficient at the primary and secondary levels, while it became less efficient at the tertiary education level.

The implication of the above mixed empirical outcomes is that, Government expenditure and other variable inputs in the education sector may be characterised by inter-spatial or cross-sectional heterogeneity, suggesting that what play out at a specific time period or in a given nation/region may be totally different from what holds in another. It is therefore imperative that, this study revisit the manner in which budgetary allocations to the education sector have been managed over the years, and further explores the nature of impact running from public expenditure on education to education outcomes in the context of Nigeria.

\subsection{Relative trends in Migrant's Remittances, Public Expenditures on Education and School enrolments in Nigeria}

Statistical report from the World Bank (2018) reveals the volume of migrant's remittances received from 1981 to 2017 . In 1981, about $\$ 13.39$ million was received as migrants' remittances. This figure however plummeted to about $\$ 10.45$ million, and thereafter, it rose to about N99.18million and N17.362billion in 1991 and 1994 respectively. Migrants' remittances received in Nigeria oscillated between $\mathrm{N5.47}$ billion and $\mathrm{N300.34billion}$ between 1995 and 2005. In addition, the average remittance received from Nigerians in the Diaspora 
between 2006 and 2015 was $\$ 2.86$ trillion. It however attained it peak of about $\$ 6.325$ trillion in 2016 after which it dropped to about $\$ 6.017$ trillion in the year 2017. Figure 1 reports this trend.

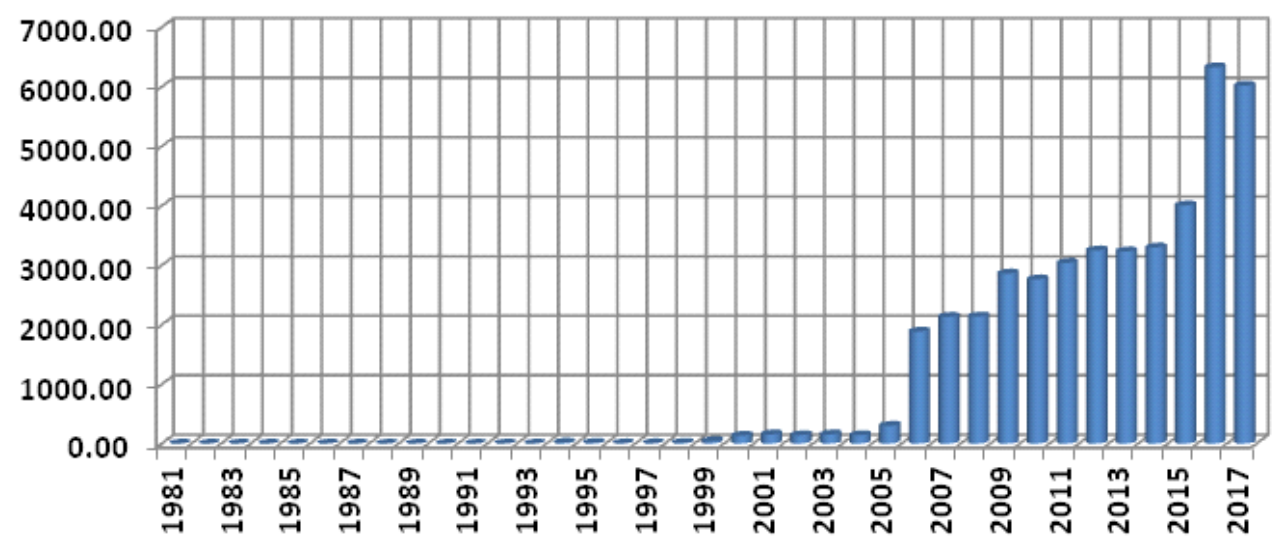

Figure 1: Migrants's remittances received (NBn)

Source: Underlying data from World Development Indicators of the World Bank (2018)

Furthermore, Figure 2 displays the trends in Public expenditure on education in Nigeria from 1981 to 2017. From the figure, budgetary allocations to the education sector stood at N0.17billion in 1981. It however increased to about \$3.01billion in 1989 but declined to about 0.29billion in 1992 after which it increased to about $\$ 57.96$ billion in the year 2000 . Government expenditure on education however fluctuated between $\$ 39.88$ billion and \#170.80billion from 2001 and 2010. The figure rose to about $\$ 390.42$ billion in 2013 and further reached it all time high of about $\$ 394$.90bllion in 2017. The figure 2 shows the trend in budgetary allocations to the education sector for the 37-year period (1981-2017) in Nigeria.

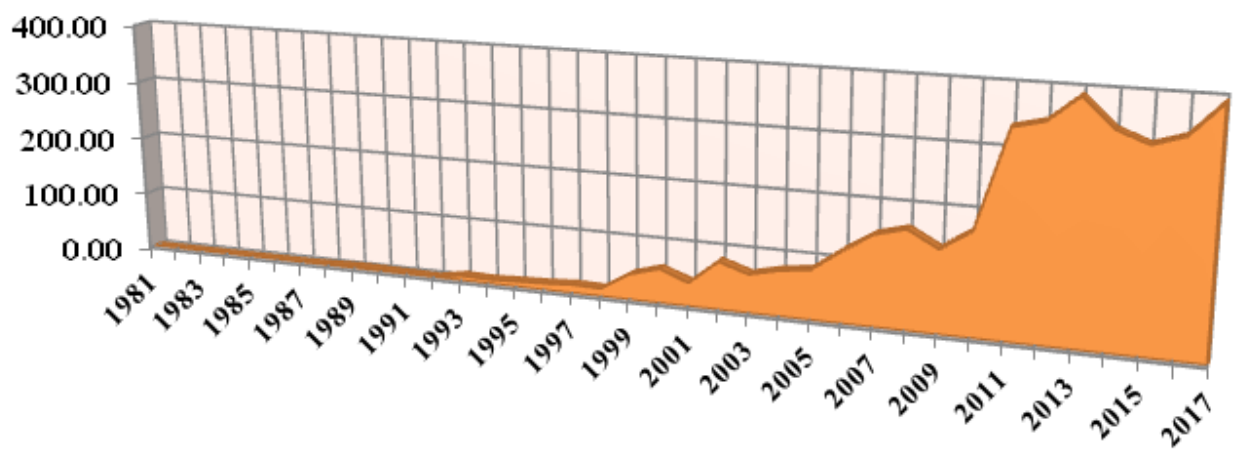

Figure 2: Public Expenditures on Education (NBN)

Source: Underlying data from Central Bank of Nigeria Statistical Bulletin (2017)

In similar vein, Figure 3 shows the trends in Secondary School enrollment in Nigeria between 1981 and 2017. The figure reports that, Secondary School enrollment rate in Nigeria stood at about 17.10 percent after which it grew to about 29.32 percent in 1985 . The figure further rose to about 33.01 percent in 1988, but then declined slightly to about 32.46 
percent in 1992. The average secondary school enrolment rate in Nigeria was 33.08 percent between 1993 and 2008. The country however experienced the highest rate of about 56.18 percent in 2013 after which the figure declined to about 41.98 percent in 2016 , before rising to about 45.92 percent in 2017.

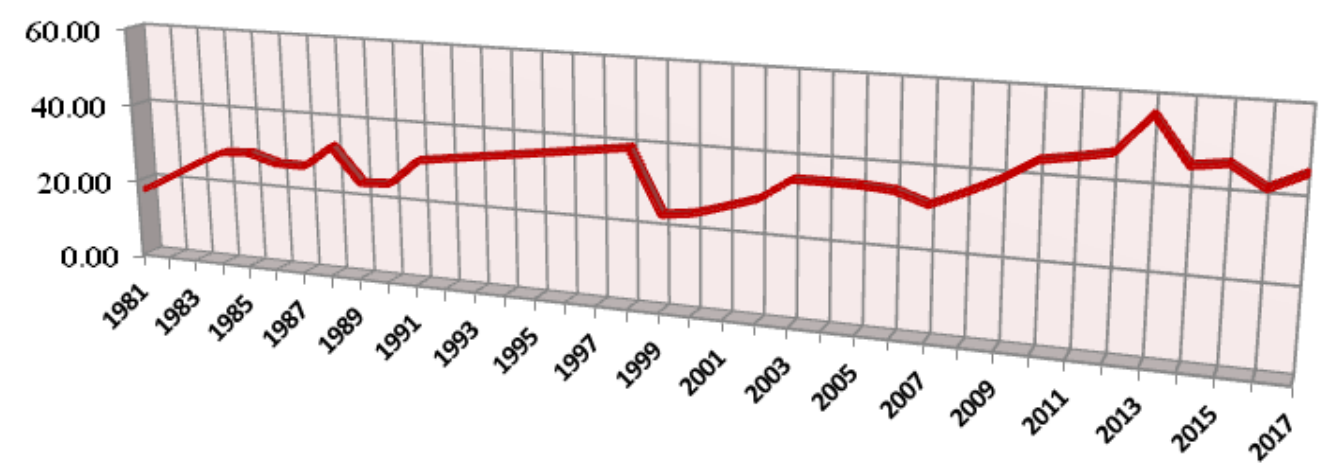

Figure 3: Secondary School enrolment (\% gross)

Source: Underlying data from World Development Indicators of the World Bank (2018)

\section{Methodology and Model Specification}

This segment covers the description of research design adopted in migrants' remittances, Public expenditure on education and their implications for educational development in Nigeria. These include theoretical framework, model specification, method of data collection as well as the method adopted in analysing the data for this study.

\subsection{Theoretical Underpinnings}

The theoretical framework of this study is predicated on the Human capital investment theory advanced by Becker (1975), though with slight modifications. Becker (1975), in the theory, delineated the various transmission channels between income, expenditure and human capital development. The idea is that increasing income enables individuals to channel more financial resources in the direction of improved quality of education which translates into higher human capital development. The relevance of this theory is that it reveals the mechanism through which expenditure on education impacts on human capital development. From the foregoing, this study will regress education outcome on Government spending on education and other relevant macroeconomic fundamentals.

\subsection{Model Specification}

Drawing on the reviewed literature and the theoretical basics of the study, the theoretical model is specified below;

SSER=F(MREM, PEXED, PCI, PGR).

Supposing a linear association exists amongst the above variables, following previous studies (for instance, Schady, 2002; Dauda, 2011; Ude and Ekesiobi, 2014), the above functional relation can be re-specified in an estimable Error Correction modelling framework presented as follows; 


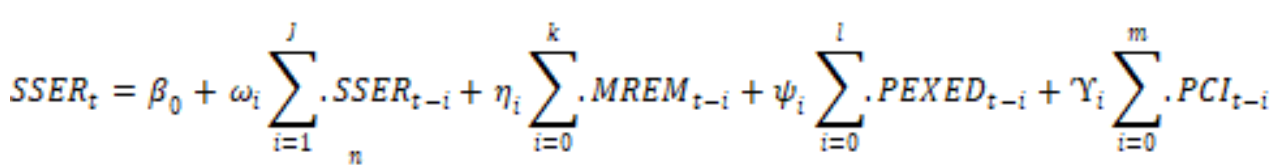

$$
\begin{aligned}
& +\alpha_{i} \sum_{i=0}^{n} \cdot P G R_{t-i}+\xi E C M_{t-1}
\end{aligned}
$$

Where, $\omega_{\mathrm{i}} \eta_{\mathrm{i}}, \Psi_{\mathrm{t}},{ }^{\prime} Y_{\mathrm{i}} \omega_{\mathrm{i}}$ are the impacts measuring parameters of the respective variables captured in the model. However, the following restrictions are imposed;

$$
\begin{aligned}
& \frac{\delta S S E R_{t}}{\delta S S E R_{t-1}}=\omega>0, \frac{S_{S S E R_{t}}}{\delta M R E M_{t-i}}=\eta>0, \frac{S S E R_{t}}{\delta P E X E D_{t-i}}=\psi>0, \frac{S S E R_{t}}{\delta P C I_{t-i}}=\Upsilon \\
& >0, \frac{\operatorname{SSER}_{t}}{\delta P G R_{t-i}}=\alpha>0, \xi<0
\end{aligned}
$$

Where SSER=Secondary School enrolment rate (the dependent variable), MREM=Migrant's remittances, PEXED=Public expenditure on education, $\mathrm{PCl}=$ Per Capita Income growth rate, $P G R=$ Population growth rate, $t=$ time, $i=l a g$ length, $E C M=$ Error correction term, which determines the speed of adjustment to long run equilibrium and $\mu=$ stochastic disturbance term that encapsulates all other variables not captured in the model. $\beta_{0}=$ the intercept in the model, $\eta_{\mathrm{i}}, \psi_{\mathrm{t}},{ }^{\prime} Y_{\mathrm{i}}$ and $\alpha_{\mathrm{i}}$ are the impacts measuring parameters of the respective variables captured in the model, $\partial$ indicates the first difference of the respective variable which is given as $X_{\mathrm{t}}-X_{\mathrm{t}-1}$. Where $X_{t}$ could be any variable and $X_{t-1}$ is the lagged series under consideration.

\subsection{Methodology}

This study adopted co-integration and error correction procedure (ECM) to examine issues relating to migrants' remittances, Public expenditure on education and their implications for educational development in Nigeria. The variables were tested for unit root, following the method advanced by Dickey and Fuller (1981) and complemented by Phillip and Perron (1988). The idea of using the Phillip-Perron test hinges on its robustness in the face of autocorrelation and time dependent Heteroskedasticity. After that, the study considered co-integration test for possible linear combination of long run relationship among variables by adopting the Johansen rank test.

\subsection{The Data}

The data set for this study includes annual time series covering the period 1981-2017, sourced from the World development indicators of the World Bank and Central Bank of Nigeria (2017) Statistical year Book.

\section{Discussion of Findings and Policy Implications}

This section is devoted to the presentation and discussion of the various findings of the study as well as their implications for policies.

\subsection{Descriptive Statistics}

The summary statistics of the variables for the study are reported in Table 1. Considering the time range of the study (1981-2017), and the frequency of the data set (yearly), all the series have 37 observations. As shown by the corresponding statistics, only Population growth rate and Secondary School enrolment rate were normally distributed. The Jarque-Bera statistics as well as their corresponding probability values simultaneously prove the null hypotheses of 
normality at 5\% significance level. In addition, migrants' remittances received and GDP per capita growth rate were leptokurtic, while Public Expenditures on Education, Population growth rate and Secondary School enrolment rate had low kurtosis values, suggestive of platykurtic distributions. All variables (except GDP per capita growth rate) were positively skewed in their distribution.

Table 1: Descriptive Statistics of all Variables Used

\begin{tabular}{|c|c|c|c|c|c|}
\hline Statistic & $\begin{array}{c}\text { Migrants } \\
\text { remittances } \\
\text { received }\end{array}$ & $\begin{array}{c}\text { GDP per } \\
\text { capita } \\
\text { growth } \\
\text { rate }\end{array}$ & $\begin{array}{c}\text { Public } \\
\text { Expenditures } \\
\text { on Education }\end{array}$ & $\begin{array}{c}\text { Population } \\
\text { growth } \\
\text { rate }\end{array}$ & $\begin{array}{c}\text { Secondary } \\
\text { School } \\
\text { enrolment } \\
\text { rate }\end{array}$ \\
\hline Mean & 1136.69 & 0.58 & 101.19 & 2.58 & 34.15 \\
\hline Median & 41.58 & 1.64 & 39.88 & 2.59 & 34.44 \\
\hline Std. Dev. & 1780.92 & 5.47 & 134.09 & 0.07 & 8.54 \\
\hline Skewness & 1.47 & -0.89 & 1.18 & 0.10 & 0.37 \\
\hline Kurtosis & 4.22 & 4.52 & 2.85 & 1.73 & 2.82 \\
\hline Jarque-Bera & 15.55 & 8.41 & 8.56 & 2.57 & 0.87 \\
\hline Probability & 0.00 & 0.01 & 0.01 & 0.28 & 0.65 \\
\hline Observations & 37 & 37 & 37 & 37 & 37 \\
\hline
\end{tabular}

Source: Author's Computation Using E-Views 10

\subsection{Stationarity Test}

Study by Granger and Newbold (1977) discloses that, most time series variables always drift in non-stationary fashion. Thus, using such non-stationary series might result in spurious regression outcomes. Therefore, the Augmented Dickey-Fuller (ADF) and Phillips-Perron (PP) tests were considered with a view to determining the stationarity position of the variables considered in the study. The ADF test minimizes the Akaike information criterion (AIC) while the Phillips-Perron test borders on the Bartlett Kernel technique while the bandwidth is chosen in line with the Newey-West method. The results are reported in Table 2.

Table 2: Augmented Dickey Fuller and Philips Perron Unit Root Tests

\begin{tabular}{|c|c|c|c|c|c|c|}
\hline Variable & $\begin{array}{l}\text { ADF test } \\
\text { statistic }\end{array}$ & $\begin{array}{c}\text { ADF } \\
\text { Critical } \\
\text { values }\end{array}$ & 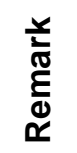 & $\begin{array}{l}\text { PP test } \\
\text { statistic }\end{array}$ & $\begin{array}{l}\text { PP critical } \\
\text { values }\end{array}$ & 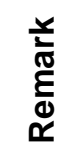 \\
\hline MREM & -5.34 & $-3.63^{* * *}$ & $\mathrm{I}(1)$ & -5.34 & $-3.63^{* * *}$ & $\mathrm{I}(1)$ \\
\hline $\mathrm{PCl}$ & -9.83 & $-3.63^{\star * *}$ & $\mathrm{I}(1)$ & -9.88 & $-3.63^{* * *}$ & $\mathrm{I}(1)$ \\
\hline PEXED & -5.18 & $-3.63^{\star * *}$ & $\mathrm{I}(1)$ & -5.13 & $-3.63^{* * *}$ & $\mathrm{I}(1)$ \\
\hline PGR & -5.01 & $-3.63^{\star * *}$ & $\mathrm{I}(1)$ & -4.38 & $-3.63^{* * *}$ & $\mathrm{I}(1)$ \\
\hline SSER & -6.71 & $-3.63^{\star * *}$ & $I(1)$ & -7.13 & $-3.63^{* * *}$ & $\mathrm{I}(1)$ \\
\hline
\end{tabular}

Source: Author's Computation Using E-Views 10 Note: ${ }^{* *}$ denote significance at $1 \%$

From the stationarity results in Table 1, both the Augmented Dickey Fuller and Philips Perron Unit Root tests indicate that all the variables became stationary at first difference (at 1 percent level). Next, we check if there is a long run association among the series employed in the study. 


\subsection{Testing for Co-integration}

Cointegration tests are generally conducted to assess the presence or otherwise of long-run relationship among the series in a regression model. This paper therefore espoused the procedure advanced by Johansen (1988) and Johansen and Juselius (1990). By employing the approach provided by Johansen and Juselius (1990), the Max-Eigen and Trace tests were considered in evaluating the number of possible cointegrating vectors. Table 3 reports the results gotten from the Johansen cointegration rank test.

The test statistics however rejects the null hypothesis of no cointegration. On the other hand, the results reveal the existence of two (2) cointegrating vectors from the Trace test statistic at both 5 percent and 1 percent levels while the Max-Eigen test statistic reveal the existence of two (2) cointegrating vectors at 5 percent and one (1) cointegrating vector at 1 percent level of significance. Judging from similar findings by Pesaran (1997), the implication is that, there is a stable long run relationship among the series under investigation and this is fundamental in the area of policy design.

Table 3: Johansen Cointegration Test results

\begin{tabular}{|c|c|c|c|c|c|c|}
\hline $\begin{array}{c}\text { Null } \\
\text { Hypothesis }\end{array}$ & $\begin{array}{c}\text { Trace } \\
\text { Statistics }\end{array}$ & $\begin{array}{c}\text { Critical } \\
\text { value at 5 } \\
\text { percent }\end{array}$ & $\begin{array}{c}\text { Critical } \\
\text { value at 1 } \\
\text { percent }\end{array}$ & $\begin{array}{c}\text { Max-Eigen } \\
\text { Statistics }\end{array}$ & $\begin{array}{c}\text { Critical } \\
\text { value at 5 5 } \\
\text { percent }\end{array}$ & $\begin{array}{c}\text { Critical } \\
\text { value at 1 } \\
\text { percent }\end{array}$ \\
\hline$\gamma=0$ & $105.78^{\star *}$ & 68.52 & 76.07 & $48.45^{\star *}$ & 33.46 & 38.77 \\
\hline$\gamma \leq 1$ & $57.33^{* *}$ & 47.21 & 54.46 & $28.82^{*}$ & 27.07 & 32.24 \\
\hline$\gamma \leq 2$ & 28.51 & 29.68 & 35.65 & 16.66 & 20.97 & 25.52 \\
\hline$\gamma \leq 3$ & 11.86 & 15.41 & 20.04 & 11.75 & 14.07 & 18.63 \\
\hline$\gamma \leq 4$ & 0.11 & 3.76 & 6.65 & 0.11 & 3.76 & 6.65 \\
\hline
\end{tabular}

Note: $\gamma$ represents number cointegrating vectors ${ }^{* *}\left({ }^{\star}\right)$ denote significance at $1 \%(5 \%)$

Source: Author's Computation Using E-Views 10

\subsection{The Parsimonious Error Correction Estimates}

Having shown that the variables are stationary and co-integrated, we now proceed to estimate the parameters of the parsimonious error correction relations in order to capture the short-run dynamics that ensued in estimating the long-run cointegrating equations. The parsimonious error correction model achieves this by offering an error correction term (ECM). In this regard, the error correction term makes it possible for us to measure the speed at which Secondary School enrolment rate adjusts to its long-run convergence. All the variables in under investigation are stationary and as such, Least Squares technique gives reliable estimates (Enders, 1995). The estimates of the parsimonious error correction model are presented in Table 4 below. 
Table 4: Parsimonious Error Correction Estimates

Dependent Variable: D(SSER)

Method: Least Squares

\begin{tabular}{|c|c|c|c|c|}
\hline Variable & Coefficient & Std. Error & t-Statistic & Prob. \\
\hline $\mathrm{C}$ & 0.64 & 0.27 & 2.40 & $0.02^{\star *}$ \\
\hline $\mathrm{D}(\mathrm{SSER}(-1))$ & 0.10 & 0.07 & 1.47 & 0.15 \\
\hline $\mathrm{D}(\mathrm{MREM})$ & 0.31 & 0.08 & 3.92 & $0.00^{* *}$ \\
\hline $\mathrm{D}(\mathrm{PEXED})$ & 0.03 & 0.01 & 2.22 & $0.03^{* *}$ \\
\hline $\mathrm{D}(\mathrm{PCI})$ & 0.09 & 0.05 & 1.70 & $0.10^{*}$ \\
\hline $\mathrm{D}(\mathrm{PGR})$ & -20.66 & 8.45 & -2.45 & $0.02^{\star *}$ \\
\hline $\mathrm{ECM}(-1)$ & -0.57 & 0.06 & -9.49 & $0.00^{* *}$ \\
\hline R-squared & 0.82 & \multicolumn{2}{|c|}{ Akaike info criterion } & 5.93 \\
\hline Adjusted R-squared & 0.68 & \multicolumn{2}{|c|}{ Schwarz criterion } & 6.24 \\
\hline F-statistic & 7.24 & \multicolumn{2}{|c|}{ Hannan-Quinn criter. } & 6.03 \\
\hline Prob(F-statistic) & 0.00 & \multicolumn{2}{|c|}{ Durbin-Watson stat } & 2.05 \\
\hline
\end{tabular}

Note: ${ }^{* * *}$ denote significance at $1 \%,{ }^{* *}$ denote significance at $5 \%,{ }^{*}$ denote significance at $10 \%$ Source: Author's Computation Using E-Views 10

The empirical findings from the table above reveal that, both migrants' remittances, Public expenditures on Education and Per Capita Income growth rate exert positive impact on educational development in Nigeria. This is suggestive of the fact that, an appreciable improvement in these economic fundamentals would not only boost the rate of Secondary School enrolment, but also guarantee some level of stability in the nation's economy. In addition, migrants' remittances received were found to be significant at 1 percent, Public expenditures on Education at 5 percent, Per Capita Income growth rate at 10 percent, while Population growth rate (though negatively impact on Secondary School enrolment rate) was found to be statistically relevant at 5 percent level.

Interestingly, our finding on the significant positive relationship between Migrants' remittances received and educational development substantiates earlier findings by Adams (2005), Mansuri (2006), Adams et al. (2008), Valero-Gil (2008) and Yang 2008. Likewise, this study reveals that, public expenditures on education positively impact on educational development. This further corroborates previous findings of Ebejer and Ulrike (2009), Okonkwo (2014), Ude and Ekesiobi (2014), Adowaa (2014) as well as Jackson, Rucker and Persico (2015), who at one time or the other examined the above subject matter, though, employed different proxies.

Also, the coefficient of one period lagged error correction term (ECM $(-1))$ is correctly signed. The implication is that, about 57 percent of the previous year's dynamics in Secondary School enrolment ratesis reconciled every twelve months and this is also significant at 1 percent level. Interestingly, this indicates a high speed of adjustment which is vital in policy analysis. In line with the submission of Kalimand Hassan (2013), a statistically significant error correction variable is an alternative avenue to corroborate the incidence of long run linkage among variables in a regression identity. Next, we examine the stability properties of the estimates in our regression model. 


\subsection{Structural Stability Analysis}

In this segment, we analysed the stability status of the coefficients of our estimated model by utilising the technique presented by Brown, Durbin and Evans (1975). This is achieved by examining the plots of the Cumulative Sum of Recursive Residual (CUSUM) and the Cumulative Sum of Squares of Recursive Residual (CUSUMsq) reported in figures (4) and (5) respectively. For all intents and purposes, there is parameters stability, if the CUSUM and CUSUMsq lie within the bands characterised by the two dotted straight lines, while the occurrence of instability is established, if the CUSUM and CUSUMsq are found outside the bands. From the graphs, both the CUSUM and CUSUMsq lie within the 5 percent critical lines, indicating parameter stability during the course of assessments. The results are however simultaneously reported below.

In this regard, all existing bottlenecks faced by migrants and remittance service providers which tend to constrain the inflow of remittance to the should be comprehensively addressed via the concerted efforts of the government and other related agencies or parastatals.

Figure 4: CUSUM

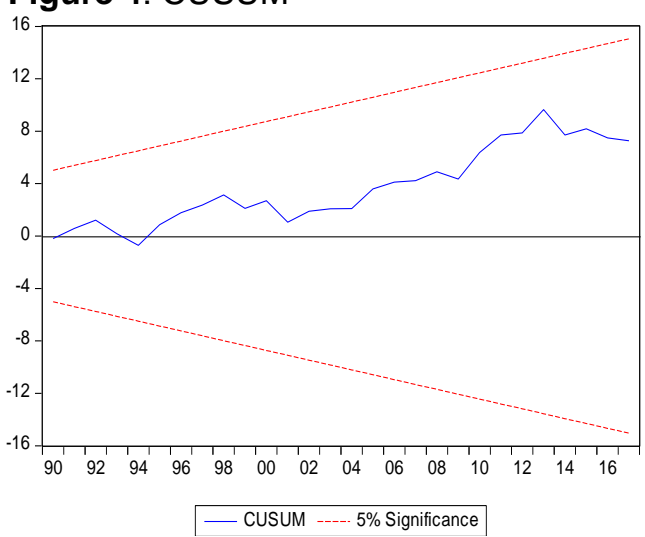

Source: Author's Computation
Figure 5: CUSUMsq

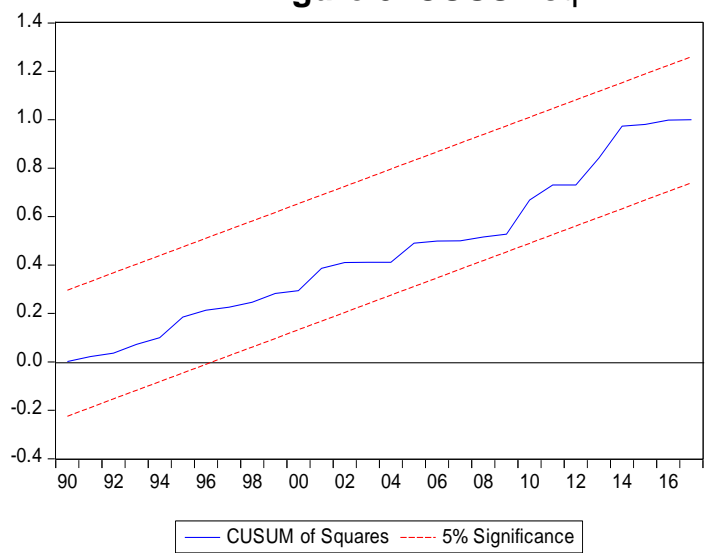

\section{Conclusion}

This study has examined migration, remittance and public expenditure on education as well as their implications for educational development in Nigeria, using secondary school enrolment rates (SSER) as a proxy for the latter for the period 1981 to 2017 . The findings of the study indicate that migrants' remittances received, public expenditures on education and per capita Income growth rate exert statistically significant positive impacts on educational development in the country, while the association turned negative in the case of population growth rate. The fundamental role played by both migrants' remittances received and public expenditures on education in stimulating educational development was evidently established in the study.

The above findings therefore suggest the need to adopt strategic measures that will help boost the rate of school enrolment in the country. This can be achieved by encouraging migrants' remittances through continuous engagement of Nigerians in the Diaspora in the country's political and socio-economic affairs. Also, there should be progressive increment in budgetary allocations to the nation's education sector, as well as enhancing the per capita income of the country through investments in key sectors of the nation's economy.

In this regard, all existing bottlenecks faced by migrants and remittance service providers which tend to constrains the inflow of remittances to the recipients in the domestic economy should be comprehensively addressed via the concerted efforts of the government and other related agencies and parastatals. 


\section{References}

Acosta, P., 2011. School attendance, child labour, and remittances from international migration in El Salvador. Journal of Development Studies, 47 (6), pp. 913 -936.

Adams, R. H., Cuecueccha, A. and Page, J., 2008. Remittances, Consumption and Investment in Ghana. Policy Research Working Paper, No. 4515, World Bank.

Adowa, B., 2014. Does public expenditure management matter for education outcomes? Development Southern Africa, 31 (4), pp. 535-552.

Al Mamun, M., Sohag, K., Uddin, G.S. and Shahbaz, M., 2015. Remittance and domestic labour productivity: evidence from remittance recipient countries. Econometric Modelling. 47, pp. 207-218

Edwards, A. and Manuelita U., 2003. International Migration, Remittances, and Schooling: Evidence from El Salvador, Journal of Development Economics 72 (2), pp. 429-61, available at, <www.nber.org/papers/w9766> [Accessed on $2^{\text {nd }}$ March, 2019]

Bang, J. T., Mitra, A., and Wunnava, P.V., 2016. Do remittances improve income inequality? An instrumental variable quantile analysis of the Kenyan case. Econometric Modelling. 58, pp. 394-402.

Becker, G., 1975. Human capital. Chicago: Chicago University Press.

Benedictis, G. Calfat, G. and Jara, K., 2010. Assessing the Impact of Remittances on Child Education in Ecuador: The Role of Educational Supply Constraints, Institute of Development Policy and Management Working Paper/2010.06, Belgium: University of Antwerp.

Brown, R. I., Durbin, J. and Evans, M., 1975. Techniques for testing the constancy of regression relationships overtime. Journal of the royal statistical society, 37, pp. 149-163.

Cattaneo, C., 2010. Migrants' Transfers and Educational Expenditure: Empiric al Evidence from Albania. FEEM Working Paper No 2010.001, Fondazione Eni Enrico Mattei, Milano.

Charles, U. O., Sylvester, C. E., Stephen, K. D., and Emilia, M. M. 2016. Government Education Spending and Education Outcome in Nigeria. International Journal of Economics, Finance and Management Sciences, 4 (4), pp. 223-234. doi: 10.11648/j.ijefm.20160404.18

Cox, E. A. and Manuelita U., 2003. International migration, remittances, and schooling: Evidence from El Salvador. Journal of Development Economics, 72 (2), pp. 429-461.

Dauda, R., 2011. Effect of public educational spending and macroeconomic uncertainty on schooling outcome: Evidence from Nigeria. Journal of Economics, Finance and Administrative Science, 16 (31), pp. 7-21.

David, M. and Hillel R., 2006, Can Migration Reduce Educational Attainment? Evidence from Mexico. New York: The World Bank, 2006, http://elibrary.worldbank.org/content/workingpaper/10.1596/1813-9450-3952.

Dickey, D. A. and Fuller, W.A., 1981. Likelihood ratio statistics for autoregressive time series with a unit root. Econometrica, 49 (4), pp.1057-1072. doi.org/10.1016/j.eneco.2010.08.003. Ebejer, I., and Ulrike, M., 2009. The efficiency of public expenditure in Malta. Economic Analysis from the European Commission's Directorate General for Economic and Financial Affairs, 6 (2), pp.1-6.

Enders, W., 1995. Applied Econometric Time Series. New York: John Wiley.

Gapen, M.T., Chami, R., Montiel, P.J., Barajas, A. and Fullenkamp, C., 2009. Do Workers' Remittances Promote Economic Growth? WP/09/153. International Monetary Fund.

Giuliano, P., and Ruiz-Arranz, M., 2009. Remittances, financial development, and growth. Journal of Development Economics. 90 (1), pp. 144-152.

Granger, C. W. J. and Newbold, P., 1977. The Time Series Approach to Econometric \Model Building, In C.A. Sims (ed.) New Methods in Business Cycle Research. Proceeding from a Conference at the Federal Reserve Bank of Minneapolis. 
Ime, O. U., 2016. Public Expenditure on Education and Human Capital Development in Nigeria, International Journal of Development Strategies in Humanities, 6 (1), pp.71-92. Jackson, C. K., Rucker C., and Persico, C., 2015. The effects of school spending on educational and economic outcomes: Evidence from school finance reforms. NBER Working Paper No. 20847.

Johansen, S. (1988), Statistical analysis of cointegration vectors. Journal of Economic Dynamics and Control, 12 (2-3), pp. 231-254.

Johansen, S. and K. Juselius, (1990). Maximum Likelihood Estimation and Inference on Co-integration - With Applications to the Demand for Money. Oxford Bulletin of Economics and Statistics, 52, pp. 169-210.

Kalim, R. and Hassan, M. S., 2013. Military expenditure and poverty in Pakistan: A complex phenomenon. Proceedings of $3^{\text {rd }}$ International Conference on Business, School of Business and Economics, University of Management and technology, Lahore, Pakistan.

$\mathrm{Li}, \mathrm{X}$., and Zhou, J., 2013. An economic analysis of remittance of unskilled migration on skilled-unskilled wage inequality in labour host region. Econometric Modelling. 33, pp. 428-432.

$\mathrm{Li}, \mathrm{X}$., and Zhou, J., 2015, Environmental effects of remittance of rural-urban migrant. Econometric Modelling. 47, pp. 174-179.

Lu, Y. and Donald J. T., 2007. Effect of labour migration and remittances on children's education among blacks in South Africa. CCPR Working Paper 001-97, California Center for Population Research. University of California, Los Angeles.

Mansuri, G., 2006. Migration, school attainment, and child labour: evidence from rural Pakistan. World Bank Policy Research Working Paper 3945.

McMahon, W., 1999. Education and development, measuring the social benefits. New York: Oxford University Press.

Medina. C. and Cardona, L., 2010. The Effects of Remittances on Household Consumption, Education Attendance and Living Standards: The Case of Colombia. Lecturas De Economía. 72 (Enero-Junio 2010), pp. 11-43.

Mingat, A., and Tan, J., 1992. Education in Asia: A comparative study of cost and financing. Washington, D. C: World Bank.

Okeke, B. C., 2014. Impact of public sector spending on health and education outcomes in Nigeria. An M. sc dissertation submitted to the department of Economics, University of Nigeria, Nsukka.

Okonkwo, S. C., 2014. Perception of parents on over schooling of children at the pre-primary education in Onitsha. A thesis submitted to the Department of Education Foundations, Faculty of Education, University of Nigeria, Nsukka.

Oriakhi, D. E. and Ameh, G., 2014. Government Expenditure and the Development of the Education Sector in Nigeria, Review of Public Administration and Management, 3(5), 2315-7844. Retrieved from www.arabianjbmr.com/RPAM index.php on 4th, February, 2019.

Pesaran, M.H., 1997. The role of economic theory in modeling the long-run. The Economic Journal, 10, pp. 178-191

Phillips, P.C.B., and Perron P. (1988), Testing for a unit root in time series regression. Biometrika, 75 (2), pp. 335-346.

Prabal K. De and DilipRatha, 2012. Impact of remittances on household income, asset and human capital: evidence from Sri Lanka, Migration and Development, Routledge, 1 (1), pp. 163-179 retrieved from http://dx.doi.org/10.1080/21632324.2012.719348

Rao, B.B. and Hassan, G.M., 2011. A panel data analysis of the growth effects of remittances. Econometric Modelling. 28 (1-2), pp.701-709.

Rapoport, H. and Frédéric D., 2005. The Economics of Migrants' Remittances. Institute for the Study of Labour (IZA), Bonn. 
Ratha, D. 2007. International Remittances and the Household: Analysis and Review of Global Evidence. World Bank Policy Research Working Paper No. 4116. Washington D.C.: World Bank.

Richard H. and Adams. Jr., 2005. Remittances, Household Expenditure and Investment in Guatemala. Working Paper no. 3532, The World Bank Group, 2005, http://elibrary.worldbank.org/content/workingpaper/10.1596/1813-9450-3532

Richard, A., 2005. Remittances, Household Expenditure and Investment in Guatemala, Policy Research Working Paper 3532. The World Bank.

Schady, N., 2002. The (Positive) effect of macroeconomic crises on the schooling and employment decisions of children in a middle-income country. Development Research Group: The World Bank.

Seife, D. and Susan, P., 2005. Remittances, Child Labor, and Education in Ethiopia (paper presented at the Mid-west Economics Association annual meeting, Milwaukee, WI, March 11-13, http://www.docstoc.com/docs/39154711/Remittances-Child-Labor-and-Education.

Tiongsan, E., 2002. The effectiveness of government spending on education and health care in developing and transition economics. European Journal of Political Economy, 18 (4), pp. 717-737.

Ude, D., and Ekesiobi, S., 2014. Panel investigation of states social spending and social outcome: Perspective of education in Nigeria. International Journal of Economics, Finance and Management 3 (5), pp. 244-255.

Valero-Gil, J., 2008. Remittances and the Household's Expenditure on Health. MPRA Paper, No. 9572, University Library of Munich, Germany.

Williams, K., 2017. Do remittances improve political institutions? Evidence from Sub-Saharan Africa. Econometric Modelling. 61, pp. 65-75.

World Bank, 2016. World Development Indicators. Washington, DC, World Bank Group.

World Bank Development Prospects Group, 2006. Global Economic Prospects 2006: Economic Implications of Remittances and Migration. Washington, DC: The World Bank Group, http://go.worldbank.org/GHQWWAQX60.

Yang, D., 2008. International Migration, Remittances and Household Investment: Evidence from Philippine Migrants' Exchange Rate Shocks. The Economic Journal, 118 (528), pp. 591-630.

Ziesemer, T. H., 2012. Worker remittances, migration, accumulation and growth in poor developing countries: survey and analysis of direct and indirect effects. Econometric Modelling, 29 (2), pp. 103-118.

\section{Bionotes}

Sunday Osahon Igbinedion is a Senior Lecturer in the Department of Economics, Faculty of Social Sciences, University of Benin, Nigeria. His main research fields are international finance, econometrics, health economics and energy economics. He has published about 45 academic articles (20 in peer-review international journals), authored 2 academic books. $\mathrm{Dr}$ Igbinedion is in the editorial board of 5 national and 2 international journals.

Clement Atewe Ighodaro is an Associate Professor in the Department of Economics, Faculty of Social Science, University of Benin, Nigeria. His areas of interest are economic development, industrial economics, applied econometrics, macroeconomics and mathematical economics. He has published about 50 academic articles (24 in peer-review international journals) and authored 3 academic books. Dr Ighodaro is the current Head of Department of Economics, University of Benin and is in the editorial board of 6 national and 3 international journals. 